\title{
Resisting the 19th Century Colonial Politics of Exile: The Study of Kiai Ahmad Arrifai Kalisalak and Kiai Hasan Maolani Kuningan Letters
}

\author{
M. Adib Misbachul Islam", Muhammad Nida' Fadlan ${ }^{2 *}$, Abdullah ${ }^{3}$ \\ Universitas Islam Negeri Syarif Hidayatullah Jakarta, Indonesia; e-mail: adib@uinjkt.ac.id \\ 2 Universitas Islam Negeri Syarif Hidayatullah Jakarta, Indonesia; e-mail: m.nida@uinjkt.ac.id \\ 3 Universitas Islam Negeri Syarif Hidayatullah Jakarta, Indonesia; e-mail: abdullah@uinjkt.ac.id \\ * Correspondence
}

Received: 2020-12-13; Accepted: 2021-07-25; Published: 2021-08-10

\begin{abstract}
This article aims to reveal the discourse on the resistance of two Javanese ulama who were victims of the Dutch colonial politics of exile in the 19th Century. This study uses several letter manuscripts written by Kiai Ahmad Arrifai Kalisalak and Kiai Hasan Maolani Kuningan from their exile as primary sources. The letters addressed to his family and followers in Java were written in Javanese with the Pegon script. Through historical studies and discourse analysis, this study finds that the Dutch colonial politics of exile was not able to dampen the resistance of the ulama. The writing of letters from exile by Kiai Ahmad Arrifai Kalisalak and Kiai Hasan Maolani was intended to compete with the colonial powers, producing heretical discourses and disturbing public order as a pretext to banish them. Thus, this article concludes that the two ulama did from their exile was a new mode of resistance against colonialism.
\end{abstract}

Keywords: Discourse analysis; exile; Kiai Ahmad Arrifai Kalisalak; Kiai Hasan Maolani Kuningan; Letter manuscript; power relations; resistance.

Abstrak: Artikel ini bertujuan untuk mengungkap wacana perlawanan dua ulama Jawa yang menjadi korban politik pengasingan kolonial Belanda pada abad ke-19. Kajian ini menggunakan sumber primer berupa manuskrip surat yang ditulis oleh Kiai Ahmad Arrifai Kalisalak dan Kiai Hasan Maolani Kuningan dari tanah pengasingan. Surat-surat yang ditujukan untuk keluarga dan pengikutnya di Jawa tersebut ditulis dalam bahasa Jawa dengan aksara Pegon. Melalui kajian historis dan analisis wacana, kajian ini membuktikan bahwa politik pengasingan yang dilakukan oleh pemerintah kolonial Belanda tidak mampu menghentikan perlawanan kedua ulama tersebut Penulisan surat-surat dari tanah pengasingan yang dilakukan Kiai Ahmad Arrifai Kalisalak dan Kiai Hasan Maolani ditujukan untuk menandingi kuasa kolonial yang memproduksi wacana sesat dan pengganggu ketertiban umum sebagai dalih untuk mengasingkan keduanya. Dengan demikian, penulisan surat-surat oleh kedua ulama tersebut dari tanah pengasingan merupakan modus baru perlawanannya terhadap kolonialisme.

Kata Kunci: Analisis wacana; Kiai Ahmad Arrifai Kalisalak; Kiai Hasan Maolani Kuningan; manuskrip surat; pengasingan; perlawanan; relasi kuasa. 


\section{Introduction}

The 19th Century was a crucial period in the history of Muslims in Java. At that time, there were many resistance and social protest movements in response to colonialism. Therefore, it is not an exaggeration if Sartono Kartodirdjo, a historian, considers that 19th century Java was a time of social upheaval (Kartodirjo, 1978, pp. 13-15).

Various resistance movements against colonialism in Java involved ulama. Besides the armed resistance movement, the ulama also expressed their resistance against colonialism in the form of a messianic movement, as shown by Kiai Hasan Maolani (Ricklefs, 2005), and a cultural isolation movement led by Kiai Ahmad Arrifai Kalisalak (Djamil, 2001).

On the other hand, the colonial government used a particular strategy to extinguish the people's resistance movement led by the ulama. In this case, the colonial government often chose the exile strategy. It separated the ulama from the people by arresting and sending them to a place far from their origin. In the case of 19th century Java, Prince Diponegoro, Kiai Modjo, Kiai Ahmad Arrifai Kalisalak, and Kiai Hasan Maolani, were victims of colonial government exile policy.

Historically, the 19th-century practice of exile by penghulu (marriage registrar/officer; religious affairs officer) against those who threatened their rule is nothing new. Hilmar Farid's study (2013, p. 137) revealed that the colonial government was able to send disobedient people through its military in the past, including the ulama. The colonial government banished them to the areas under the control of the Dutch colonial government, which spread from South Africa to Ambon.

Interestingly, despite being in exile, the ulama were able to establish communication with the outside world through written media. Various written works such as books, treatises, letters, and creative works emerged from the exile land (Farid, 2013). Kiai Ahmad Arrifai Kalisalak is an example of a Kiai who continued to write scripts in the form of tanbih (warning) to his followers in Java when he was exiled to Ambon, Maluku. Meanwhile, Kiai Hasan Maolani wrote 14 letters when he was exiled to Tondano, North Sulawesi, from 1854 to 1855.

Studying these texts based on many manuscripts written by Kiai Ahmad Arrifai and Kiai Hasan Maolani in the exile camp above is crucial. The significance of the study of letters from the exile is based on the fact that the writing of letters by both Kiai was another way of resisting colonial powers.

Due to the explanation above, this article aims to prove that writing letters in the exile land are a new form of resistance waged by Kiai Ahmad Arrifai and Kiai Hasan Maolani. In addition, in the context of unequal power relations, this article is also intended to prove that exile is a new field for the resistance of both Kiai who became victims of colonial government politics in the 19th Century.

\section{The Ulama of Archipelago and the Politics of Exile}

In the context of Indonesian history, along with the entry of colonialism in the archipelago, political history in Indonesia is closely related to the practice of exile. Since its arrival in the 16th Century, the Dutch trading company Vereenigde Oostindische Compagnie (VOC) has often contacted local authorities such as kings, nobles, and clergy. For the sake of its economic desires, the VOC was present in various social conflicts among communities in the archipelago by showing its alignment with one of the opposing groups. If the party it supported won the dispute, the VOC would punish the opposing leader by exiling him to a distant place without having a court of law mechanism (Kembuan, 2016, pp. 29-30; Ward, 2009, pp. 185-187).

So far, most authoritative references do not expose the beginning of the application of the exile practice in the archipelago. Referring to the existing literature, exile in the archipelago has been implemented since the 17th Century, with Sheikh Yusuf al-Makassari as the primary victim because of his involvement in the ranks of Sultan Ageng Tirtayasa in fighting the colonials. As a consequence of his participation, in 1683, the VOC exiled him to Ceylon before being transferred to Cape Town until he died in 1695 (Ricklefs, 2005).

In the 18th Century, the practice of colonial exile also occurred in the archipelago. Suryadi's study (2008, pp. 216-217) mentions that Fakhruddin Abdul Khair, a leader of the Kingdom of Gowa 
(1753-1767), was exiled to Ceylon. The VOC took action to secure its trading political interests in the Eastern Archipelago because it felt threatened by a British trading company named The East India Company, in which Sultan Fakhruddin protected its existence.

In the early 19th Century, VOC bankruptcy and the takeover of power by the Dutch colonial government did not abolish the practice of exile. Through the policy exorbitante rechten, a governorgeneral had full authority to take action against a person or group deemed to be endangering the order of the colony. One of the actions was exiling a person or group either within the colony (interneering) or out of the territory (externeering). ${ }^{1}$

In Ward's view (2009, pp. 185-187), an exile is a tool used by colonial rulers to control the influence of local rulers. Cribb (2011, p. 37) even referred to the practice of exile as a repressive act of the colonial government in response to the stiff resistance of the natives. Since its implementation from 1855 to 1920, Cribb (2004, p. 140) recorded more than 1,150 cases of the exorbitante rechten at the expense of the natives.

Interestingly, out of the many social classes being targets of exile by the Dutch colonial government in the 19th Century, the ulama were the essential element. The colonial bureaucrats assumed that the trigger for the resistance movement never came from the consciousness of each native but came from the planting of external doctrines, thus triggering the emergence of friction between the natives and colonials (Farid, 2013). These doctrines emerged from scholars, including ulama, who instilled the importance of safeguarding the sovereignty of their ancestral lands so as not to be taken for granted by the colonials.

Evoking love for the homeland caused the community to place the ulama in a respectable position as a source of community role models. In addition to being the heirs of prophetic values, in specific contexts, it is not uncommon for ulama if their followers set them as saviors or messiahs of justice who can save their lives from all the threats faced, including the threat of seizure of the sovereignty of their ancestral lands by the colonial government (Kroef, 1952, p. 61; Ricklefs, 2007, p. 47). In addition, the community recognises that the ulama are important figures in the community who can play a role as educators of Islamic teachings, guardians of local wisdom, and leaders of political movements (Burhanudin, 2012). Therefore, it is not surprising that the ulama eventually became the main target of exile by the colonial government.

\section{Manuscripts of Letters and Discourses}

Kiai Ahmad Arrifai Kalisalak's letter is stored in the Leiden University Library and registered with the number and code: Cod. Or. 11.004/Mal. 6168 (figure 1). The manuscript consists of 518 written pages and 26 blank pages (518 pages). The manuscript consists of three texts: first, the Takhyirah text, from page 1 to page 19; second, the text of Kiai Ahmad Arrifai's letter when he was exiled in Ambon to his son-in-law, namely Kiai Maufura from page 31 to page 48; and the third, nazham texts of the Tarekat, starting from page 69 to page 518. Each page consists of 11 lines, except the first page, which consists of 9 lines, and the last page, which consists of eight lines. The manuscript is $21.3 \times 16.5 \mathrm{~cm}$, while the text is $14.8 \times 10.5 \mathrm{~cm}$. The cover of the manuscript is made of light brown leather with a floral-geometric motif.

Letter texts are generally written in Javanese with the Pegon script. However, there are some Malay vocabularies. It is due to the presence of Kiai Ahmad Arrifai while in Ambon, who interacted a lot with the Muslim community in Ambon who use the Malay language as their daily

${ }^{1}$ Kembuan (2016, pp. 33-34) notes that there are three types of privileges of the governor general in applying punishment, namely: (a) expulsion or verbanning, which is a form of punishment for people who endanger order and security in the colony but they are still given freedom of movement; (b) exile in the territory or interneering, i.e. the punishments given to people deemed to have thoughts and influences that endangered the Colonial Government thereby disrupting public order; and (c) exile outside the territory or externeering, i.e. the punishment given to foreign nationals (not Dutch East Indies-born) deemed to disturb public order. 
communication. The khat (Arabic inscription) used the Naskhi type. The used ink is black, except for the preamble of Arabic letters written in red ink.

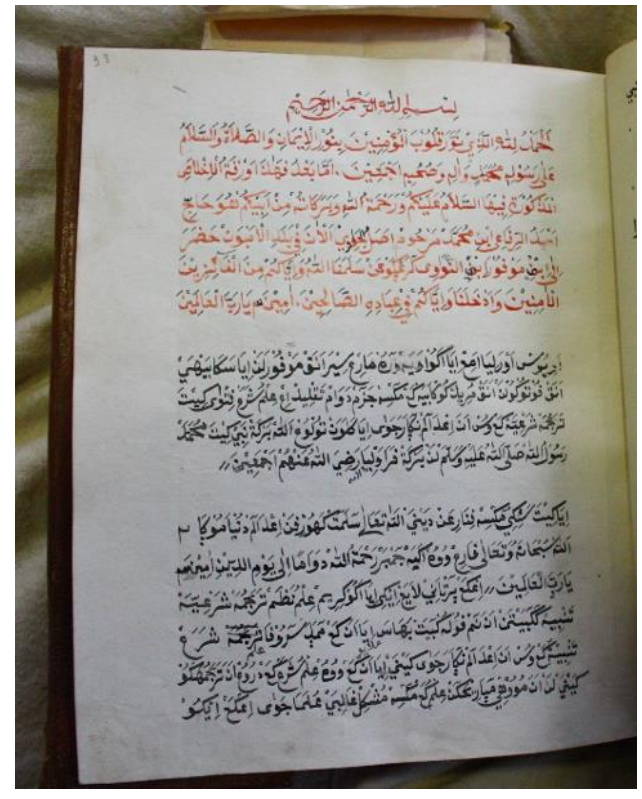

Figure 1 Script of Kiai Ahmad Arrifai Kalisalak's Letter

\section{Leiden University Library Collection Cod. Or. 11.004/Mal. 6168}

The condition of the manuscript is good. The writing is clear and easy to read. The text of the letter in this manuscript contains Kiai Ahmad Arrifai's message to his children and students in Java to consistently adhere to his teachings as contained in the Tarajjumah book and information about his latest works while in Ambon. The text begins with basmalah, praises to Allah, and blessings to the Prophet Muhammad and his family. Then, followed by the narrative of Kiai Ahmad Arrifai about the background of sending letters to Java. The final text contains his greetings to his children and students in Java as well as requests for prayers for safety. On the last page of the letter, there is a colophon of the completion of the writing of the text, namely Thursday, 21 Zulhijjah in the Year of Jim Awal or coinciding with the year 1277 Hijriyah/June 30, 1861). In addition, at the end of the letter, there is information that the letter was copied by Haji Muhammad Busyra on 16 Safar 1340 H/19 October 1921.

As for Kiai Hasan Maolani's letters², the searches in the field managed to find a bundle of copied manuscripts duplicated by the Annual Commemoration Committee of Eyang Hasan Maolani 1990 (figure 2). The copies were collected by Moh. Ma'ruf entitled Amanat Eyang Hasan Maolani dari Pembuangan Penjajah Belanda di Menado, Sulawesi Utara, untuk Keturunannya yang Harus Dipelajari, Diresapi, dan Dilaksanakan dengan Sepenuh Hati Sesuai dengan Isi Buku Aslinya or Mandate of Syaikh Hasan Maolani from the Exile of the Dutch Colonials in Menado, North Sulawesi, for His Descendants who must be Studied, Absorbed, and Carried Out Wholeheartedly in Accordance with the Contents of the Original Book (1990).

Due to the sorting of these copies, Kiai Hasan Maolani wrote these letters from 1854 to 1855. It is based on the conversion of Kiai Hasan Maolani's letters originally written in Javanese (AJ) and Hijri (AH) calendar systems. Based on the conversion results carried out by Fadlan (2015b, pp. 37-39), the oldest letter was written on June 2, 1854, while the last letter was written in January/February 1855.

\footnotetext{
${ }^{2}$ In this section, the manuscript descriptions written mostly refer to Fadlan $(2015,34-45)$. The urgency of reinventory is because researchers get the latest information on the existence of the original manuscript after the research conducted by Fadlan in 2013-2015 ended. Although in the end the researchers failed to get the original manuscript physically for ethical reasons as the researchers before.
} 


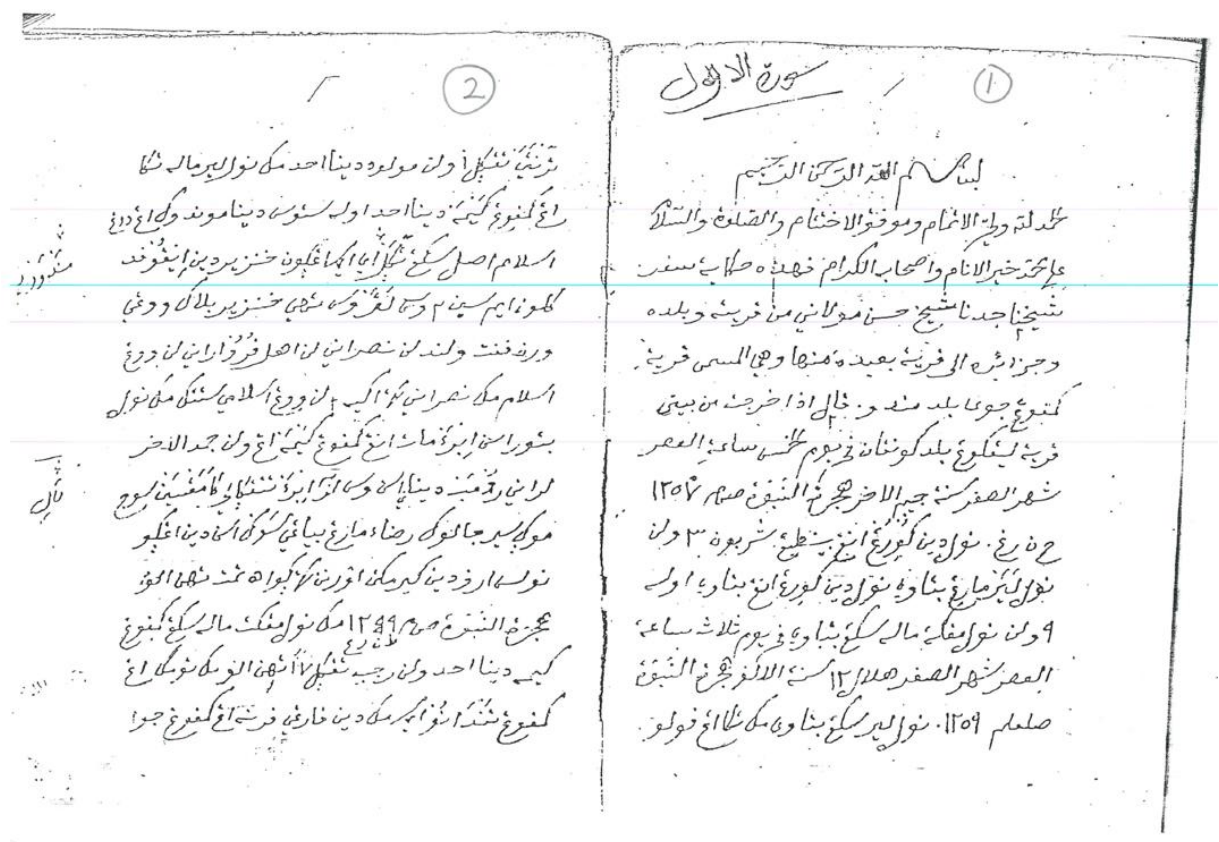

Figure 2 Copy of Kiai Hasan Maolani's Letters (Ma'ruf, 1990)

It is important to note, the emergence of letter texts written by Kiai Ahmad Arrifai and Kiai Hasan Maolani mentioned above originated from the political decisions of the colonial government due to the consideration both Kiai were disruptors of public order and security. Thus, the decision that they are troublemakers is a discourse built by the authorities.

Concerning the relationship between discourse and power, the emergence of letters from exile land was naturally a counter-discourse against the dominant discourse formed by the colonial government. In Foucault's view (1969, p. 220), discourse is not some language signs that refer to what is being discussed, but rather systematic-specific practices in a specific pattern of relations. In his elaboration of the discourse concept, Foucault in Deleuze (1986, p. 55) asserts that discourse is part of a knowledge system closely related to power. Regarding the relationship between knowledge and power, Foucault (1976, pp. 20,124) sees that power is not a monopoly on one party, individuals, or institutions but spread to various parties. Thus, power is spread and owned by multiple parties.

\section{Kiai Ahmad Arrifai and Kiai Hasan Maolani in the Politics of Exile}

Kiai Ahmad Arrifai was born on November 13, 1786 AD, in Tempuran village, precisely in a house located south of Kendal Great Mosque, Central Java. His mother's name is Siti Rahmah, and his father's name is Muhammad Marhum, the son of RKH Abu Sujak, aka Sutjowidjojo, a leader of Landraad Kendal (Djamil, 2001, p. 13).

Kiai Ahmad Arrifai spent his childhood studying Islamic sciences at an Islamic boarding school built by KH. Asy'ari, a great scholar and founder of the Kaliwungu Islamic Boarding School (Amin, 1989, p. 10, 1997, p. 42). As he matured, after having sufficient religious knowledge, Kiai Ahmad Arrifai began to carry out preaching into the community. In his preaching activities, he often made strong criticisms of the attitude of some people who supported the Dutch colonial government. Therefore, it is not surprising that Kiai Ahmad Arrifai's critical attitude in preaching finally caused a stern warning from the local Dutch government. Even the Dutch government hold him for several days in prison without a court process (Amin, 1997, p. 50).

After his release from prison, Kiai Ahmad Arrifai intended to go to Mecca to perform the pilgrimage while studying in the holy land. In 1833, he went to Mecca twice to perform the pilgrimage and then stayed there for eight years (Djamil, 2001, p. 13; Ismawati, 2005) 
After returning from Mecca, he carried out preaching in the Kendal community. At first, he delivered preaching material only focused on the practical needs of the community related to the issues of worship and muamalah. Therefore, it did not arouse suspicion from the colonial government (Amin, 1997, p. 59).

After the colonial government found out what was behind his preaching material, there was much resistance against the colonial government. The colonial government finally took action to stem the influence of Kiai Ahmad Arrifai. The colonial government took steps to raise the controversial sides of his thought to pit between Kiai Ahmad Arrifai and other Kendal community leaders (Amin, 1997, p. 59). The colonial government's efforts resulted in the emergence of complaints from traditional bureaucrats and religious leaders to the Kendal court alleging that Kiai Ahmad Arrifai's teachings had disturbed the public peace. The impact of the protest led the court to decide that he was not allowed to live in Kendal. It made him move to Kalisalak, a remote village in Batang district, Central Java, where he established an Islamic boarding school (Amin, 1997, pp. 60, 62; Djamil, 2001, p. 16).

Even though he had moved to a remote place, Kiai Ahmad Arrifai's spirit of resistance to the invaders did not subside. Gradually, his movement increasingly disturbed the Dutch government. At least three times, the Resident (District authority) of Pekalongan, namely Franciscus Netscher, reported the activities of Kiai Ahmad Arrifai and his followers to the Governor-General of the Dutch East Indies, namely Governor-General Pahud. Then, Governor-General Pahud requested Kiai Ahmad Arrifai to be exiled. However, the Dutch government did not grant this effort immediately (Darban, 2004, pp. 50-51; Fahmi, 2008, p. 26; Steenbrink, 1984, pp. 101-102).

Finally, the Regent of Batang sent a letter to the Resident of Pekalongan, namely Fransiscus Netscher, containing a complaint regarding the actions of Kiai Ahmad Arrifai on April 24, 1859. For the second time, he sent it on May 6, 1859. A resident of Pekalongan called Kiai Ahmad Arrifai to answer the allegations against him so that the exile requirements were met as well (Fahmi, 2008, p. 27; Steenbrink, 1984, pp. 102-105). Based on the examination, the Governor-General put Kiai Ahmad Arrifai in exile to Ambon with his decree No. 35 on May 9, 1859. The decision was based on the consideration that Kiai Ahmad Arrifai was a politically dangerous figure because he did not want to obey the local authority appointed by the Dutch government. Besides, he also remains influential among his students who often visited him (Steenbrink, 1984, p. 113).

Not much different from Kiai Ahmad Arrifai, Kiai Hasan Maolani is a native son born in Lengkong Village, which is currently part of the Garawangi District in Kuningan Regency, West Java Province. He was born on Monday, at 5 o'clock, the 8th of Jumadil Akhir 1196 Hijri, or coincided with May 21, 1782.

Kiai Hasan Maolani has been accused that he carried out the doctrine of syncretisation of Islamic religious teachings. It was said that he encouraged the people to perform a ceremonial offering called slametan by serving a pottery plate containing certain foods. The implementation of the ceremony was a suggestion from a supernatural whisper received by Kiai Hasan Maolani so that he would avoid the devil's temptation. In this regard, the Government of the Dutch East Indies labeled him "Tjap Setan" (follower of the devil) because, according to the Colonial Government, he taught the Muslims the erroneous teachings of Islam and set an alliance with the devil. His teachings have caused restlessness among Muslims in the Priangan area (Drewes, 1925, p. 11).

The colonial government saw that Kiai Hasan Maolani had high charisma in the eyes of his followers. He had a wide association, and the surrounding community respected him. He had many students gathered in the "Raudlatut Thalibin" Islamic boarding school (Marhamah, 2005). Research by Laffan (2011, pp. 51-52, 106-107) mentioned that his popularity became a critical note for the then Head of Raad van Indie, Jan Isaac van Sevenhoven, when he visited this Islamic boarding school in 1839. The colonial government regarded Kiai Hasan Maolani 'new danger' because many people visited him to study. The report led the colonial government to arrest and exile him outside Java (Drewes, 1925, pp. 13-15). 
Kiai Hasan Maolani was arrested in Safar 1257 Hijri (March/April 1841) at 59 years old. From the beginning, the family did not approve of the arrest because there was no clear allegation (Tisnawerdaya, 1975, p. 69). However, realising the powerful colonial position, Kiai Hasan Maolani forbade his family to oppose the decision. Instead of going through physical resistance, he advised them to take the diplomatic route by meeting Raden Dipati Majalengka to lobby the colonial government (Fadlan, 2015b, p. 31).

After two years of arrest, he arrived in the exiled land of Kampung Jawa Tondano (now Minahasa Regency, North Sulawesi). This exile decision was without a proper court process. The colonial government summoned him. Then, based on Governor-General Pieter Mercus's decree on June 6, 1842, Kiai Hasan Maolani was decided to be exiled to Manado as a state prisoner status (Kembuan, 2016, p. 57).

He became a respected figure in the exile camp and lived with the clerics involved in the Java War (1825-1830) such as Kiai Modjo (Kiai Halifah), Kiai Wahada, Kiai Baderan, Kiai Ghazali, and Kiai Ma'ruf. On April 29, 1874, the family in Kuningan, West Java, received a letter informing Kiai Hasan Maolani's death in exile.

Kiai Ahmad Arrifai and Kiai Hasan Maolani's biographies above show that both kiai were victims of the colonial government's political exile to separate them from their followers. The colonial government hoped that sending them away from his followers could disconnect their relationships, and his leadership's influence would fade away. Thus, the colonial government could spread the power quickly (Fadlan, 2015a, p. 105; Suryadi, 2008).

\section{Letters and Resistance from The Exile}

The presence of Kiai Ahmad Arrifai in Ambon was a result of the colonial government's political decisions against various activities carried out by him in calling against the colonial rulers in Kalisalak, Batang. In the process of Kiai Ahmad Arrifai's examination in Pekalongan court lead by Fransiscus Netscher, he was accused of inciting the Muslim community and disobedience to local authorities. Tumenggung Aria Puspadiningrat (Regent of Batang), Raden Witiswodjo (Prosecutor of Pekalongan), and Johannes Nijzelar (secretary of the residency) also attended the examination (Steenbrink, 1984, p. 109).

Several issues emerged in the process of Kiai Ahmad Arrifai examination. Those are the teachings of Kiai Ahmad Arrifai that were written in his books, the establishment of his Islamic boarding school in Kalisalak, his harsh statement against the colonial government, his incitement to the people to oppose rulers, his suggestion to the students to be kept away from the colonial government, the absence of reporting of his students to wedono (local authority), his conduct of remarrying the married couples who have been married off by penghulu (marriage registrar) and put the label of infidel to whoever cooperated and served the infidel colonialism (Steenbrink, 1984, pp. 109-113).

Based on the above allegations, the Governor-General's decision no. 35 on May 9, 1859, contained the exile of Kiai Ahmad Arrifai out of Java. The decision was based on the consideration that Kiai Ahmad Arrifai did not want to obey the local authority appointed by the Dutch government. Therefore, he was considered a political danger. In addition, the Governor-General saw that many of his students often visited him, which could jeopardize the colonial power (Steenbrink, 1984, p. 113). This decision was highly political than legal. Therefore, during the prosecution of Kiai Ahmad Arrifai, he was not given his right to defend himself, nor witnesses presented.

The process of examining Kiai Ahmad Arrifai, which led to his exile to Ambon, showed an unequal power relationship between the colonial government and Kiai Ahmad Arrifai. In this power relation, the colonial government used its power to summon and examine Kiai Ahmad Arrifai. Then, the colonial government labeled him a dangerous figure and had to be exiled outside Java. As stated by Foucault (1976, pp. 20, 124), power is spread, not just becoming a one-party monopoly. In this case, the colonial government used its power to decide that Kiai Ahmad Arrifai was a dangerous figure, so he had to be exiled. Although he seemed unable to oppose the Governor General's decision, it did not 
mean that he had no power at all. His attitude in exile later became his way of using his influence in countering the politics of the colonial government of exile.

Farid (2013, p. 135) stated that among the aims of the Dutch colonial government's exile politics are to separate the prime figures from their followers that the Dutch colonial government considered dangerous and reduce their potential resistance. The exile politics to banish the influenced figure away from one place is a strategic choice to fulfill the intended goals. However, this goal did not always as expect because, like in Kiai Ahmad Arrifai, the relationship between him and his followers remains intact. Thus, he was able to convey his teaching, including his call to resist colonialism. In his letters, Kiai Ahmad Arrifai also has asked his followers to reply to his letters so that he kept informed regarding the situation faced by his follower in fighting against colonialism.

The presence of Kiai Ahmad Arrifai's letter to his followers as a form of his resistance to the colonial government's exile politics is increasingly visible. It can be seen in its' contents a call to his followers to maintain justice. Kiai Ahmad Arrifai (1861, p. 32) wrote in his letter:

... to all my students, do not be ignorant, do not change the heart to be credulous and do the right deeds as much as possible, to spread justice and hold to be a truthful person in providing the correct and credible information alhamdu lillahi rabbil 'alamin [praise be to Allah, the Lord of the universe].

The opening of the letter above clearly reveals that his followers must uphold justice. It is undeniable that justice is a moral discourse that Kiai Ahmad Arrifai always conveyed in his books. Although the concept of fairness initiated by him stems from the teachings of figh (Islamic jurisprudence), as shown in his book Tarajjumah, his justice concept is directly related to the sociopolitical situation in Java during the colonial period. His sharp criticism of the priyayi (elites) and the rulers at that time was based on the loss of justice due to their submission to the infidel colonial government. This strong criticism led the Governor-General of the Dutch East Indies to decide that Kiai Ahmad Arrifai had rebelled against the Dutch government's local rulers.

In addition, the justice discourse initiated by Kiai Ahmad Arrifai is also directly related to the colonial government's policy of interfering with the religious justice system during the colonial period. In this context, the penghulu (religious affairs officer), whose duties were to carry out some of the Islamic laws relating to marriage and the management of waqf property (Pijper, 1985, pp. 73-80), had to be under the colonial government. In his view, the law that applies in Java is the thaghut (Idolatrous/unIslamic/agent of Western) law. Therefore, the ulama who work in religious courts under the authority of the colonial government naturally serves the thaghut law. According to Kiai Ahmad Arrifai, those who follow the thaghut law are misguided and misleading. In his letter, Kiai Ahmad Arrifai (1861, p. 33) said:

Beware, several ulama have fallen into the category of ignorant and do not follow Allah's guidance that could benefit the hereafter. They are voluntarily following the customary law of the government set by the thaghut, and we seek refuge in God from going astray. Some ulama do not submit to the commands of Allah and the Messenger of Allah. Therefore, one should know the ulama guided by Allah. Seek refuge in Allah from heretical ulama who go astray and like to associate with the infidels.

Interestingly, Kiai Ahmad Arrifai never used the term thaghut while he was in Java. In several of his books, he only used the term state customary law for the law that prevailed at that time and the term qadhi fasik (violator of law) for those who were willing to become the rulers (Islam, 2016). Thus, the use of the term thaghut by Kiai Ahmad Arrifai in exile has a deep meaning to his attitude towards the politics of the colonial government law and the decision to exile him to Ambon.

It is important to note that the term thaghut is mentioned in the Qur'an in surah al-Baqarah: 256, 257, surah az-Zumar: 17, and an-Nisa: 60 in different contexts. Ragib al-Asfahani concluded that the use of the term thaghut in the Qur'an implies all things that exceed the limits and all gods besides Allah. Therefore, according to Ragib al-Asfahani (2008, p. 341), sorcerers, fortune-tellers, wicked jinn, and all persons who deviate from the path of truth are thaghut. 
Looking at the content of the meaning of thaghut in the Qur'an as described by Ragib al-Asfahani above, Kiai Ahmad Arrifai's use of thaghut in his letter shows that in his view, there was a crucial issue regarding the Islamic legal order in Java, including the qualifications of its legal apparatus. It is related to a fair attitude that his followers must maintain.

Inevitably, Kiai Ahmad Arrifai's detention in Semarang while still living in Kendal and his exile to Ambon began is based on the reports of several Javanese rulers. They considered his teachings and movements had deviated and disturbed the community. In this case, the Javanese rulers who got their authority from the colonial government at that time had used their power to judge him as a deviant and disturbing person. In response to the distorted and disturbing discourse produced by the ulama 'ajam who became the Javanese rulers, Kiai Ahmad Arrifai issued a counter-discourse that those who cooperated with the infidel government were followers of the thaghut law whose "heart is dark because it is covered by a large hijab (headcover) in the form of an unjust head of state which hates some of the Shari'a (Islamic law)."

In addition to the discourse of thaghut, Kiai Ahmad Arrifai also produced the discourse of the hijab, which hindered the hearts of ulama who were pro-colonial government and the discourse of injustice attached to the head of state. The production of those discourses in exile which were addressed to Javanese ulama and rulers, automatically showed that he used his power to fight against the power of the Javanese ulama and the colonial government. It is proof that although he was politically a weak party, he was still capable of showing his power against the colonial power.

In addition to the discourse of thaghut and unjust, Kiai Ahmad Arrifai also put forward the discourse of fasiq (violator of Islamic law) to Javanese clerics who were willing to become Religious affairs officers (penghulu). The discourse has emerged in contrast with justice discourse. Therefore, he considered that the Javanese penghulu was ignorant of performing Shari'a law. In his view, they did not submit to Allah's commands. His harsh attitude towards the penghulu shows that his exile in Ambon did not stop his resistance to traditional bureaucrats under the colonial government.

Based on his teaching in Java, traditional bureaucrats, including the penghulu who worked under the colonial government's rule, became the target of his strong criticism. His Tarajjumah book shows his straightforwardness in attacking these traditional bureaucrats. The culmination of his criticism of the penghulu was the loss of their legality as the official authorised to implement some Islamic law. According to Kiai Ahmad Arrifai, as a logical consequence of the loss of legitimacy, the marriage law's implementation automatically became invalid. This view led the colonial government to judge Kiai Ahmad Arrifai as a dangerous person and rebelled against the local rulers appointed by the colonial government.

The exile experienced Kiai Ahmad Arrifai is not a disaster for his family and followers to mourn. Through his letter, Kiai Ahmad Arrifai advised his followers and their families not to grieve and have mercy on him. Kiai Ahmad Arrifai (1861, p. 36) said:

Tanbih (behold), to all my posterity and students, do not regret and put pity on me because I was exiled to Ambon and considered it as sadness and dangerous disaster. On the contrary, please love yourself/6/. Beware the destruction of the religion of Allah and the Messenger of Allah in Java. Allah made a great disaster in the form of ulama who follow the mislead thaghut law for the people who want to worship.

The quote above shows that Kiai Ahmad Arrifai did not see exile as a disaster. He did not want his family and followers felt pity for him. On the other hand, a tragedy in his view is the existence of some Javanese clerics who follow the thaghut law to become misguided and misleading.

His call on his family and followers to maintain justice and keep a distance from the power of the thaghut expressed his toughness in accepting the exile decision. It emphasised his resistance to the colonial government and its officials. Thus, the writing and delivery of his letter from exile was a counter-discourse to the discourse produced by the colonial government.

The case of Kiai Ahmad Arrifai, as an ulama who resisted colonialism and was sent for exile, was also experienced by Kiai Hasan Maolani. In addition to having a large number of followers, Kiai Hasan Maolani also had an influential student who also had many followers, namely Kiai Nurhakim. 
Therefore, his activities in spreading Islam in Kuningan, West Java, eventually raised the concerns of the colonial authorities because it could attract many followers.

His experience above and the processes that led to the political decision to put him in exile indicate the link between power and knowledge that spreads to various parties. The colonial government's control over its colonial lands prompted certain efforts to secure its power. Therefore, the colonial government produced knowledge about what is wrong, misguided, and deviant to support their power and reduce potential threats to their power. In addition, Kiai Hasan Maolani, as a scholar who has deep religious knowledge, naturally can convey spiritual knowledge to the Kuningan community. Therefore, he had authority beyond the authority of the local government under the colonial government.

As previously stated, the politics of exile aims to disturb the relationship between the heroic Kiai and their followers. The geographical separation in great distance between their place of origin and the exile makes it difficult for them to keep in contact. However, it was just "temporarily" because they could use various ways to keep in communication with their followers. Kiai Hasan Maolani's experience in exile shows that the tremendous geographical distance did not become a barrier between him and his followers in Kuningan. By writing and sending letters to his family in Kuningan, he informed the situation in his exile. Based on the information in the letter, he carried out the same activities as he did in Kuningan, namely leading religious activities and teaching spiritual knowledge. In this regard, he recounted his activities (Fadlan, 2015b, p. 117):

Lan angadegaken salat Jum'ah dadi tutuné isun. Saperti dadi pangulu umpamané anikahaken iku atawa rātiban imamé iku kudu isun oranana kang wani yèn ana isun.
For the Friday prayer, I am the one who arranged it. Including being a marriage registrar or leading the reading of rātib (reciting the prayers or $d h i k r$ ) must also be me. No one dares to lead if I am present

The excerpt from the letter shows that Kiai Hasan Maolani was a leader for the community in Tondano. He had followers of 20 men and ten women. In addition, in another part of the letter, it is also stated that his followers were not limited to ordinary citizens, but also nobles from Java, namely Prince Suryaningrat and Prince Rangga.

The explanation above shows that Kiai Hasan Maolani gained new power in exile through his extensive religious knowledge. He had new followers who were not limited to ordinary citizens but also aristocrats. Thus, the letter's writing shows that the disconnect between him and his followers in Kuningan as the goal of the political exile failed. In contrast, it shows his continued power. His writing in his letter about his activities in religious life in exile become a resistance discourse produced by Kiai Hasan Maolani against the discourse produced by the colonial government that he adhered to heresy and Satanic teachings.

To cut contact between heroic exiled figures and their followers, the colonial government automatically closed the communication channels. Therefore, in the face of such colonial power, Kiai Hasan Maolani carried out resistance by sending letters secretly. Through his authority and mastery of religious knowledge, he received help from a sayyid from Surabaya to send letters to his family in Kuningan. In this regard, Kiai Hasan Maolani said (Fadlan, 2015b, p. 135).

Yā waladì wa yā ibni bintī, isun kapèngen

katemu kelawan anak putu kabèh supaya isun durung ulih dedalan. Malah-malah isun wis kirim surat pindho kira-kira wis dèn tekakaken.

Sapisan isun kirim surat kang agawa sayyid saking Surabaya, mantuné Nyai Talam Lengkong, tatkala isun teka ing Kampung
$\mathrm{O}$, my children and grandchildren, I want to meet you all, but there is no way. Even, I have sent a letter twice, and it is estimated to have arrived.

First, I sent a letter brought by a sayyid from Surabaya, son-in-law of Nyai Talam Lengkong, when I arrived in Kampung 
Kema. Kapindho kang agawa nangkoda saking Surabaya tatkala isun wis teka ing Kampung Jawa.
Kema. Second, the one who brought was a captain from Surabaya when I arrived in Kampung Jawa.

Another critical aspect to note as a form of resistance was Javanese's use of the Pegon script in writing letters. Kiai Hasan Maolani's mode of resisting the colonial government's censorship of possible contacts between political prisoners and outsiders. Based on his narrative, the colonial government implemented a regulation that correspondence must use the Malay language with Latin script, otherwise having legal consequences. Kiai Hasan Maolani recounted:

Samangsa isun arep kirim surat iku (...) ora wani anggawa iku wedi kapitnah dèning kumpeni. Iku samangsa arep akirim surat kudu bilang maring residen, kudu dèn waca ing arepané residen, basané kudu Melayu, lan tulisé kudu aksara Walanda. Mulané isun ora bisa kirim-kirim surat. Wallāhu a'lam bi al¡awāb.

Lan sekabèh perkara surat iku aja sira wartakaken ing wong akèh atawa ing wong gedé boka dadi pitnah. Ing sira umpetana kerana ceritané wis ora kena wong buwangan iku akirim surat yèn ora terang saking komandan utusan residen.
When I wanted to send a letter, no one dared to take it for fear of the Dutch government. When sending a letter, we must report to the local authority who will read it, and it must be in Malay and must be written in Dutch (Latin). That's why I can't send letters. Only Allah knows the truth (Fadlan, 2015b, p. 135).

Regarding the letter, do not let others or officials know about it. I am fear it can be libelous. Please hide it! Because the exiled person is prohibited from sending a letter without the commander's consent of the district authority (Fadlan, 2015b, pp. 160-161).

The quotes above show that writing and sending letters by Kiai Hasan Maolani to his family in Kuningan was not an easy matter. Procedurally, a political prisoner in exile must report to the district authority (the Residence) to send a letter to his family.

\section{Conclusion}

Kiai Ahmad Arrifai Kalisalak and Kiai Hasan Maolani Kuningan were two Javanese Kiai involved in the resistance movement against Dutch colonialism in the mid-19th Century. The campaign of the two ulama encouraged the colonial government to stop it through a policy of exile.

Inevitably, the colonial government's exile politics imposed on both Kiai aimed at stopping their resistance and severing their relationship with their followers in Java. The distance of geographical location between their origin and the exile at a glance can indeed break the contact between both and their followers in Java. However, the findings of some manuscripts of letters written by both Kiai to their families and followers show that it cannot stop the communication between them. The information in the letters from the exile showed that the exile originally intended to prevent the resistance movement of the two Kiai turned out to be a new field for their resistance to the colonial government. The letters from the exile containing calls to keep a distance from the colonial powers and their officials show that the burning spirit of resistance to the colonial government remained intact. Kiai Ahmad Arrifai's discourses on unjust and thaghut addressed to the colonial government, and its officers are resistances discourses to deviant discourses and public order produced by the colonial powers. Meanwhile, the letter containing information about Kiai Hasan Maolani's religious activities in exile is a resistance to the discourse of heretical teachings produced by the colonial powers.

\section{References}

Al-Asfahani, R. (2008). Mu'jam Mufradat Alfaz al-Quran (I. Syamsuddin, Ed.). Beirut: Dar al-Kutub al-Islamiyyah. Amin, A. S. (1989). Mengenal Ajaran Tarajumah Syaikh Ahmad Rifa'ie RH dengan Madzhab Syafi'i dan I'tiqad Ahlissunnah wal Jama'ah. Jakarta: Jamaah Masjid Baiturrahman. 
Amin, A. S. (1997). Gerakan Syaikh Ahmad Rifa'i dalam Menentang Kolonial Belanda. Jakarta: Jamaah Masjid Baiturrahman

Arrifai, A. (1861). Manuscript, Lor.11.004, Special Collections. Leiden: Leiden University.

Burhanudin, J. (2012). Ulama dan Kekuasaan: Pergumulan Elite Muslim dalam Sejarah Indonesia. Jakarta: Mizan Publika.

Cribb, R. (2004). Historical Dictionary of Indonesia. Lanham: Scarecrow Press.

Cribb, R. (2011). A System of Exemptions: Historicizing State Ilegality in Indonesia. In E. Aspinall \& G. van Klinken (Eds.), The State and Illegality in Indonesia. Leiden: KITLV Press.

Darban, A. A. (2004). Rifa'iyyah, Gerakan Sosial Keagamaan di Pedesaan Jawa Tengah Tahun 1850-198. Yogyakarta: Terawang Press.

Deleuze, G. (1986). Foucault. Paris: Les Editions de Minuit.

Djamil, A. (2001). Perlawanan Kiai Desa: Pemikiran dan Gerakan Islam K.H. Ahmad Rifa'i Kalisalak. Yogyakarta: LKiS.

Drewes, G. W. J. (1925). Drie Javaansche Goeroe's: Hum Leven, Onderricht en Messiasprediking. Leiden: Drukkerij A. Vros.

Fadlan, M. N. (2015a). Citra Pengasingan dalam Naskah Surat: Kajian atas Surat-surat Eyang Hasan Maolani, Lengkong. Proceedings International Conference on Nusantara Manuscripts, 97-119.

Fadlan, M. N. (2015b). Surat-surat Eyang Hasan Maolani, Lengkong: Suntingan Teks dan Analisis Isi. Universitas Indonesia.

Fahmi, A. T. (2008). Ajaran Islam dalam Kitab Husn al-Mathalib Karya Ahmad Rifa'i Kalisalak (Studi Naskah Abad XIX). UIN Syarif Hidayatullah Jakarta.

Farid, H. (2013). Pengasingan dalam Politik Kolonial. In D. Dhakidae (Ed.), Soekarno: Membongkar Sisi-sisi Hidup Putra Sang Fajar. Jakarta: Kompas.

Foucault, M. (1969). L'archéologie du savoir. Paris: Gallimard.

Foucault, M. (1976). La Volonté de savoir. Paris: Gallimard.

Islam, M. A. M. (2016). Puisi Perlawanan dari Pesantren: Nazam Tarekat Karya KH. Ahmad Arrifai Kalisalak. Tangerang: Transpustaka.

Ismawati, I. (2005). Jaringan Ulama Kendal Abad ke-19 dan 20. EDUKASI: Jurnal Penelitian Pendidikan Agama Dan Keagamaan, 3(2), 42-59. https://doi.org/10.32729/edukasi.v3i2.211

Kartodirjo, S. (1978). Protest Movement in Rural Java. Singapore: ISEAS.

Kembuan, R. A. C. (2016). Bahagia Di Pengasingan: Kehidupan Sosial Budaya Masyarakat Buangan Di Kampung Jawa Tondano (1830-1908). Universitas Gadjah Mada.

Kroef, J. M. van der. (1952). The Messiah in Indonesia and Melanesia. The Scientific Monthly, 75(3), 161-165.

Laffan, M. (2011). The Makings of Indonesian Islam: Orientalism and the Narration of a Sufi Past. New Jersey: Princeton University Press. https://doi.org/10.1515/9781400839995

Ma'ruf, M. (1990). Amanat Eyang Hasan Maolani dari Pembuangan Penjajah Belanda di Menado, Sulawesi Utara, untuk Keturunannya yang Harus Dipelajari, Diresapi, dan Dilaksanakan dengan Sepenuh Hati Sesuai dengan Isi Buku Aslinya. not published.

Marhamah, E. (2005). Sejarah Berdirinya Pondok Pesantren Raudlatut Thalibin dan Peranannya dalam Pembinaan Umat Islam di Desa Lengkong Kecamatan Garawangi Kabupaten Kuningan. IAIN Syarif Hidayatullah Jakarta.

Pijper, G. F. (1985). Beberapa Studi Tentang Sejarah Islam di Indonesia 1900-1950 (Tudjimah \& Y. Augusdin, Trans.). Jakarta: UI Press.

Ricklefs, M. C. (2005). Sejarah Indonesia Modern 1200-2004 (S. Wahono, B. Bilfagih, H. Huda, M. Helmi, J. Sutrisno, \& H. Manadi, Trans.). Jakarta: PT. Serambi Ilmu Semesta.

Ricklefs, M. C. (2007). Polarising Javanese Society: Islamic and Other Visions (c. 1830-1930). Singapore: NUS Press.

Steenbrink, K. A. (1984). Beberapa Aspek Tentang Islam di Indonesia Abad ke-19. Jakarta: Bulan Bintang.

Suryadi. (2008). Sepucuk Surat dari Seorang Bangsawan Gowa di Tanah Pembuangan (Ceylon). Wacana, Journal of the Humanities of Indonesia, 10(2), 213-245. https://doi.org/10.17510/wjhi.v10i2.194

Tisnawerdaya, A. (1975). Sajarah Eyang Hasan Maolani (Eyang Menado). Kuningan: Badan Pembina Sekolah SPIAIN Kuningan.

Ward, K. (2009). Networks of Empire: Forced Migration in the Dutch East India Company. Cambridge: Cambridge University Press. https://doi.org/10.1163/002249909X12548095554629

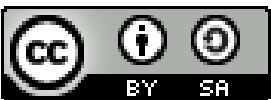

(C) 2021 by the authors. Submitted for possible open access publication under the terms and conditions of the Creative Commons Attribution (CC BY SA) license (https://creativecommons.org/licenses/by-sa/3.0/). 